
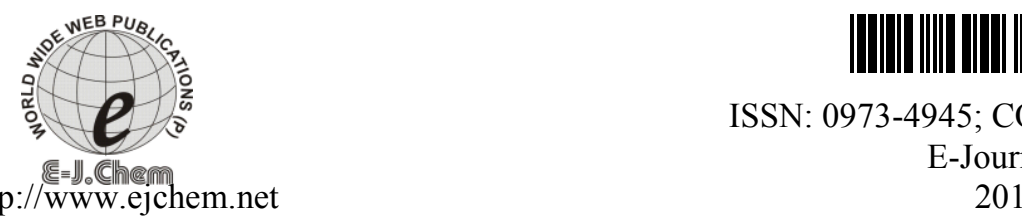

ISSN: 0973-4945; CODEN ECJHAO

E-Journal of Chemistry

2012, 9(2), 608-614

\title{
Metallic and Microbial Contaminants in Drinking Water of Cankiri, Turkey
}

\author{
EMRAH CAYLAK ${ }^{\mathrm{a}, *}$ and MUSTAFA TOKAR ${ }^{\mathrm{b}}$ \\ ${ }^{\mathrm{a}}$ Department of Biochemistry, ${ }^{\mathrm{b}}$ Department of Microbiology, \\ School of Health, Karatekin University, 18200 CANKIRI, TURKEY \\ emrah333@hotmail.com
}

Received 16 May 2011; Accepted 15 July 2011

\begin{abstract}
Safe and good quality drinking water is very important for human health. Water provides some heavy metals, such as $\mathrm{As}, \mathrm{B}, \mathrm{Cd}, \mathrm{Cn}, \mathrm{Cr}, \mathrm{Cu}, \mathrm{F}, \mathrm{Cl}$, $\mathrm{Hg}, \mathrm{Ni}, \mathrm{Pb}, \mathrm{Se}$, and $\mathrm{Sn}$. These are undesirable substances dangerous to human health and cause chronic diseases and various cancers. Coliform bacteria are a commonly used bacterial indicator of sanitary quality of water. E. coli, total coliform and enterococci have been used as indicators of possible sewage contamination might pose a health risk. In this study, water samples were taken from thirty different waterworks in Cankiri, Turkey and metallic and microbial contaminants were investigated. In the drinking tap water samples have been found at concentrations exceeding the Turkish regulations (As and free $\mathrm{Cl}$ ) and the WHO guidelines (As and B). Our results also indicate that significant microbiological contaminations were found above the guidelines for drinking waters given by the $\mathrm{WHO}$, because of the fact that in the distribution of water is not appropriate.
\end{abstract}

Keywords: Heavy metal, Drinking water, Microbiological, Arsenic, Boron, Health, Turkey.

\section{Introduction}

Safe and good quality drinking water provides some heavy metals, and it is precious resource essential for sustaining human life and health. The ultimate source of these elements is generally rocks. There are different ways of metallic contamination of drinking water such as rainwater and rivers collect metals while passing through the soil or the dangerous products from industry, agriculture and other human activities enter the rivers, lakes, and underground water. The contamination of water is also related to during the treatment, reserving and distribution processes.

Many chemicals and microbes have been reported as pollutants of drinking water. Commonly reported heavy metals include arsenic (As), boron (B), cadmium (Cd), cyanide $(\mathrm{Cn})$, chromium $(\mathrm{Cr})$, copper $(\mathrm{Cu})$, fluorine $(\mathrm{F})$, free chlorine $(\mathrm{Cl})$, mercury $(\mathrm{Hg})$, nickel $(\mathrm{Ni})$, lead $(\mathrm{Pb})$, selenium $(\mathrm{Se})$, and antimony $(\mathrm{Sn})^{1}$. Health concerns are also associated with metallic contaminants that have the ability to cause adverse health effects after prolonged 
periods of exposure. They cause serious diseases such as, reproductive, cardiovascular and neurological disease or various cancers ${ }^{2-8}$.

Commonly found in drinking water microbes include enterococcus, coliform, and $E$. Coli. The main source of microbiological contamination is microorganisms from sewage causing serious digestive tract diseases such as diarrhoea ${ }^{9}$.

The aim of this study is to determine the metallic and microbial contaminants drinking water of Cankiri and its villages and to check compliance with respect to Turkish legislation and WHO guidelines for the occurrence of toxic and/or harmful components in drinking water.

\section{Experimental}

The chemical and microbiological dataset of thirty different waterworks were obtained from the Health Directorate of Cankiri for this study. Drinking water samples were collected from centre of Cankiri City and villages from near Cankiri City in August 2009 (Table 1). Samples were collected from residential tap water according to correct sampling techniques to analyze chemical and microbiological them.

Table 1. Water sampling locations.

\begin{tabular}{lc}
\hline Location no & Location name \\
\hline I & Karatekin park \\
II & $100^{\text {th }}$ year Orphanage \\
III & Superior reservoir \\
IV & Inferior reservoir \\
V & Ahlat village \\
VI & Akcavakif village \\
VII & Akoren village \\
VIII & Alanpinar village \\
IX & Asagicavus village \\
X & Asagipelitozu village \\
XI & Asagiyanlar village \\
XII & Ayan village \\
XIII & Ayan village Deliklikaya quarter \\
XIV & Basegmez village \\
XV & Civi village \\
XVI & Civi village Dede quarter \\
XVII & Degim village \\
XVIII & Derecati village \\
XIX & Germece village \\
XX & Hasakca village \\
XXI & Hidirlik village \\
XXII & Icyenice village \\
XXIII & Inanc village \\
XXIV & Inandik village \\
XXV & Konak village \\
XXVI & Pasa village \\
XXVII & Suleymanli village \\
XXVIII & Tuzlu village \\
XXIX & Tuney village \\
XXX & Yukaricavus village \\
\hline &
\end{tabular}


The concentrations of elements $\mathrm{As}, \mathrm{Cd}, \mathrm{Cr}, \mathrm{Cu}, \mathrm{Hg}, \mathrm{Ni}, \mathrm{Pb}, \mathrm{Se}$, and $\mathrm{Sn}$ were measured using Inductively Coupled Plasma-Optical Emission Spectrophotometer (ICP-OES) (Varian Vista, Australia). As concentration in samples was measured using atomic absorption spectrophotometer (Perkin Elmer HGA 700, USA). B, F, $\mathrm{NO}_{3}{ }^{-}$, and $\mathrm{NO}_{2}{ }^{-}$were analyzed by using Ion Chromatography technique (Dionex DX-600, USA). Cn was analyzed colorimetrically (Hach) Pyridine-Pyrazalone Metot spectrofotometric kit (Merck) with Hach $\mathrm{DR} / 2500$ Spectrophotometer, USA. Determination in water of free $\mathrm{Cl}$ was also performed colorimetrically using diethyl-p-phenylenediamine. Detection and enumeration of coliform bacteria, E.coli and Enterococci was performed using membran filtration method ${ }^{10}$. The all data were analyzed descriptive statistically by software program (SPSS 15.0 for Windows).

\section{Results and Discussion}

The chemical values of the drinking water samples including $\mathrm{As}, \mathrm{B}, \mathrm{Cd}, \mathrm{Cn}, \mathrm{Cr}, \mathrm{Cu}, \mathrm{F}$, free $\mathrm{Cl}, \mathrm{Hg}, \mathrm{Ni}, \mathrm{NO}_{3}{ }^{-}, \mathrm{NO}_{2}{ }^{-}, \mathrm{Pb}, \mathrm{Se}$, and $\mathrm{Sn}$ from Cankiri-Turkey were given in Table 2. Several quality assessment studies on drinking tap water have been carried out ${ }^{12-14}$.

Table 2. Chemical values of the drinking water samples from Cankiri, Turkey $(\mu \mathrm{g} / \mathrm{L})$.

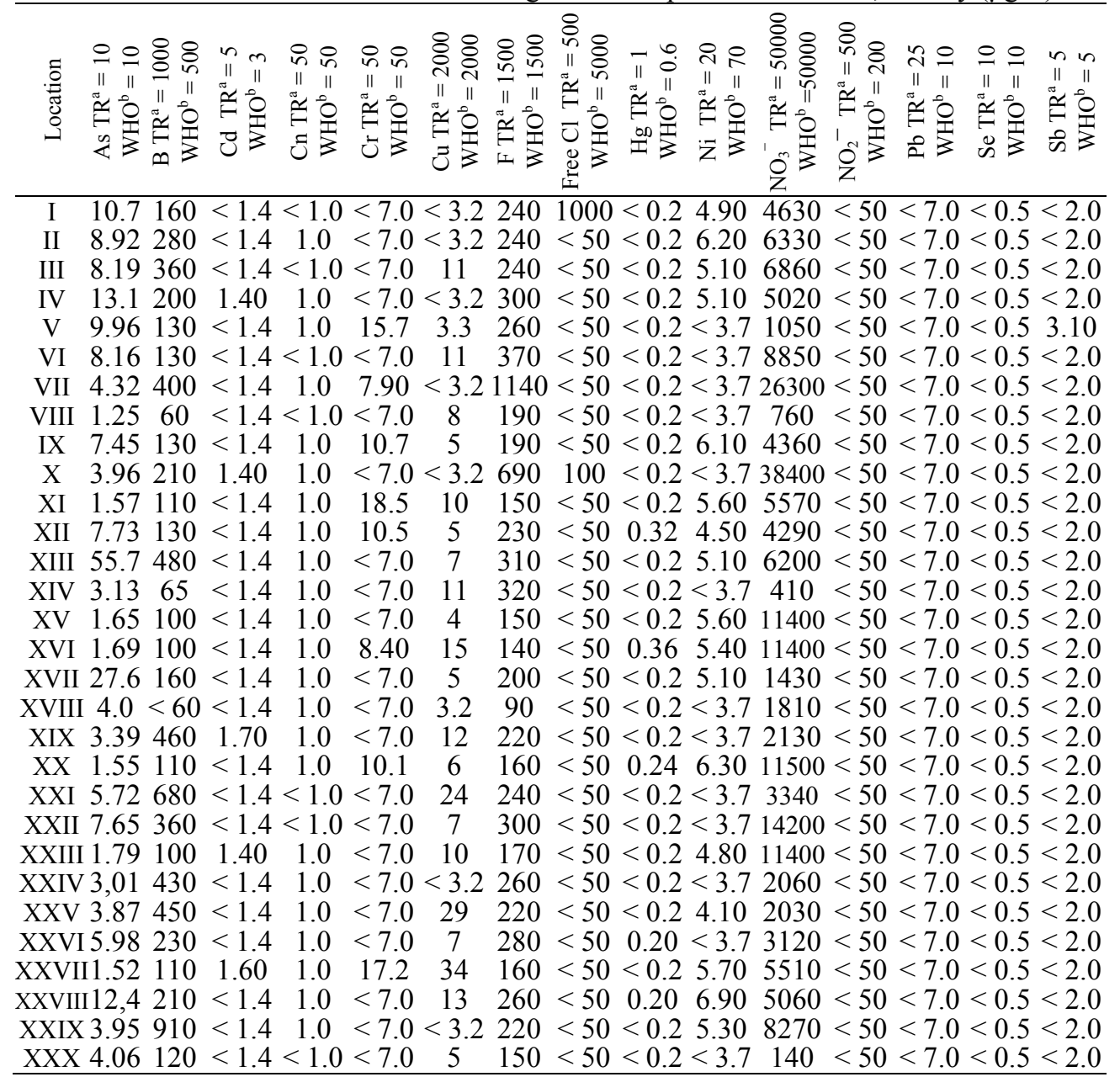

${ }^{a}$ Guide values established by Turkish legislation for drinking water ${ }^{11} .{ }^{b}$ Guideline values established by the World Health Organization for drinking water ${ }^{l}$. 
Arsenic in the investigated water samples were found in the range of $1.25-55.77 \mu \mathrm{g} / \mathrm{L}$. The arsenic values in Karatekin park and inferior reservoir at the centre of Cankiri, Ayan village Deliklikaya quarter, Degim village near Cankiri were found above the Turkish and WHO recommended value for drinking water $(10 \mu \mathrm{g} / \mathrm{L})^{1,11}$. Concentrations of arsenic in drinking water samples were found to be ranging between 10 and $50 \mu \mathrm{g} / \mathrm{L}$ in 22 points and were found to be $>50 \mu \mathrm{g} / \mathrm{L}$ in 5 stations of Aksaray in Turkey ${ }^{15}$. The presence of arsenic in water sources resulted from leaching of arsenic from rocks and sediments. It is known that long time absorption of arsenic can cause neurological, dermal, hematopoietic, reproductive, and carcinogenic (dermis and lung) diseases ${ }^{16,17}$; whereas positive relationships between low-dose As exposures and cumulative incidence ratios of bladder, lung and urinary-related cancers were recently found ${ }^{18}$.

The boron concentrations were found in the range of $<60-480 \mu \mathrm{g} / \mathrm{L}$. B in Hidirlik and Tuney village's samples was above according to the limit of $500 \mu \mathrm{g} / \mathrm{L}$ permitted by WHO in drinking waters; whereas the values of stations of 7, 13, 19, 24, $25(400-480 \mu \mathrm{g} / \mathrm{L})$ were slightly below that limit ${ }^{1}$. Col and Col (2003) found higher boron levels in waters of Kutahya-Turkey resulted from rich boron mine areas ${ }^{19}$. Boron is found naturally in groundwater, but its presence in surface water is frequently a consequence of the discharge of treated sewage effluent, in which it arises from use in some detergents, to surface waters. In laboratory animals, chronic low-level boron exposure has demonstrated to cause reduced growth, cutaneous disorders and suppression of male reproductive system function ${ }^{20}$.

Fluoride in the drinking water samples were found in the range of 90-1140 $\mu \mathrm{g} / \mathrm{L}$. F concentrations in Akoren village sample $(1140 \mu \mathrm{g} / \mathrm{L})$ slightly below the Turkish regulation and WHO guidelines established for drinking water $(1500 \mu \mathrm{g} / \mathrm{L})^{1,11}$. Ruiz-Payana et al. ${ }^{21}$ found fluoride content in wells and tap water samples of Villa Ahumada-Mexico ranged from 5000 to $5700 \mu \mathrm{g} / \mathrm{L}$. Fluoride is present in many waters, with higher concentrations often associated with underground sources in areas rich in fluoride-containing minerals. Epidemiological evidence about exposure to high concentrations of fluoride can carry an increasing risk of dental fluorosis, and progressively higher concentrations lead to increasing risks of skeletal fluorosis ${ }^{22}$.

Disinfection of drinking water in developing countries is done primarily with free chlorine, commonly available as chlorine bleach. The concentration of free chlorine should normally be such that it should not give rise to unacceptable tastes and should not normally exceed Turkish regulation $(500 \mu \mathrm{g} / \mathrm{L})$ and WHO $(5000 \mu \mathrm{g} / \mathrm{L})$ guidelines values for free chlorine $)^{1,11}$. Removing excess chlorine is important to prevent taste problems. The levels of free $\mathrm{Cl}$ in the samples were found in the range of $<50-1000 \mu \mathrm{g} / \mathrm{L}$. The value of Karatekin Park at the centre of Cankiri was above the Turkish regulation criteria. In Nakhon Pathom Municipality-China, Panyakapo et al. ${ }^{23}$ found residual concentration of chlorine in tap water and swimming pool water ranged from nondetectable to $900 \mu \mathrm{g} / \mathrm{L}$ and from nondetectable to $8510 \mu \mathrm{g} / \mathrm{L}$, respectively. Chlorine reacts with natural organic matter and/or inorganic substances occurring in water to form various chlorination by-products (CBPs) such as trihalomethanes (THMs), haloacetic acids (HAAs) and other undesirable compounds ${ }^{24}$. Toxicological and epidemiological studies have been carried out to establish relationships between levels of CBPs in drinking water and various carcinogenic, genotoxic and adverse reproductive health effects ${ }^{25}$.

The nitrate levels in all stations were ranged from 410 to $38400 \mu \mathrm{g} / \mathrm{L}$. The values of Akoren and Asagipelitozu village were slightly below Turkish and WHO recommended limits ${ }^{1,11}$. In 2003, the nitrate levels were found in the water supply Tenerife island-Spain (maximum concentration $57300 \mu \mathrm{g} / \mathrm{L}^{26}$. The important source of human exposure in drinking water to nitrate by rain and irrigation water washing through soils that have been 
treated excessively with nitrated fertilizers. Nitrates are involved in the origin of highly toxic compounds like nitrites and nitrosamines. Nitrite can produce metahaemoglobinaemia, and nitrosamines are known to cause certain cancers, adverse pregnancy outcomes, diabetes, and thyroid disorders ${ }^{27}$.

The antimony content of the samples was in the range of $<0.2-3.10 \mu \mathrm{g} / \mathrm{L}$. Sb was found in the water sample of Ahlat village $(3.10 \mu \mathrm{g} / \mathrm{L})$ and it was slightly below the recommended limits of Turkish legislation and $\mathrm{WHO}^{1,11}$. $\mathrm{Sb}$ is present in the aquatic environment as a result of rock weathering, soil runoff and human activities. There is some evidence for the carcinogenicity of certain antimony compounds by inhalation, but there are no data to indicate carcinogenicity by the oral route ${ }^{28}$.

Table 3. Microbiological values of the drinking water samples from Cankiri, Turkey (cfu/100 ml).

\begin{tabular}{|c|c|c|c|}
\hline Location & $\begin{array}{c}\text { Coliform bacteria } \\
\mathrm{TR}^{\mathrm{a}}=0 ; \mathrm{WHO}^{\mathrm{b}}=0\end{array}$ & $\begin{aligned} & \text { E.coli } \\
& \mathrm{TR}^{\mathrm{a}}=0 ; \mathrm{WHO}^{\mathrm{b}}=0\end{aligned}$ & $\begin{array}{c}\text { Enterococci } \\
\mathrm{TR}^{\mathrm{a}}=0 ; \mathrm{WHO}^{\mathrm{b}}=0\end{array}$ \\
\hline I & 0 & 0 & 0 \\
\hline II & 0 & 0 & 0 \\
\hline III & 0 & 0 & 1 \\
\hline IV & 1 & 1 & 2 \\
\hline $\mathrm{V}$ & 0 & 0 & 0 \\
\hline VI & 0 & 0 & 56 \\
\hline VII & 0 & 0 & 0 \\
\hline VIII & 0 & 0 & 1 \\
\hline IX & 0 & 0 & 1 \\
\hline$X$ & 0 & 0 & 0 \\
\hline XI & 0 & 0 & 1 \\
\hline XII & 0 & 0 & 2 \\
\hline XIII & 0 & 0 & 14 \\
\hline XIV & 1800 & 1800 & 90 \\
\hline XV & 0 & 0 & 0 \\
\hline XVI & 3 & 3 & 0 \\
\hline XVII & 0 & 0 & 2 \\
\hline XVIII & 0 & 0 & 110 \\
\hline XIX & 0 & 0 & 32 \\
\hline XX & 2 & 0 & 0 \\
\hline XXI & 0 & 0 & 1 \\
\hline XXII & 0 & 0 & 3 \\
\hline XXIII & 1 & 1 & 0 \\
\hline XXIV & 100 & 100 & 126 \\
\hline XXV & 0 & 0 & 0 \\
\hline XXVI & 500 & 0 & 3 \\
\hline XXVII & 600 & 0 & 116 \\
\hline XXVIII & 0 & 0 & 0 \\
\hline XXIX & 0 & 0 & 2 \\
\hline XXX & 0 & 0 & 2 \\
\hline
\end{tabular}

Table 3 shows microbiological contamination values found in the drinking water collected from thirty location of Cankiri. The highest E. Coli and total coliform value (1800 $\mathrm{cfu} / 100 \mathrm{~mL}$ ) were detected in drinking water collected from Basegmez village of Cankiri, while the highest Enterecocci value $(126 \mathrm{cfu} / 100 \mathrm{~mL})$ was found in samples collected from 
Inandik village of Cankiri. The presence of $E$. coli is indicative of a fecal contamination and the highly probable presence of pathogens ${ }^{29}$. In addition, the presence of these microbial contaminants in drinking water must at least be considered as a possible threat or indicative of microbiological water quality deterioration.

\section{Conclusion}

The concentrations of the investigated heavy metals $(\mathrm{As}, \mathrm{B}$, and free $\mathrm{Cl}$ ) in thedrinking water samples from Cankiri/Turkey were found above the guidelines for drinking waters given by the Turkish legislation and WHO. However, it was concluded that drinking waters in Cankiri contain low other investigated heavy metal levels. This study, therefore, recommends the government and other responsible authorities to prevent any kind of metallic and microbial contaminants into water sources that supply domestic drinking water.

\section{References}

1. World Health Organization (WHO), Guidelines for drinking water quality, $3^{\text {rd }}$ Edition, Geneva, 2008.

2. Boffetta P, Mc Laughlin J K, la Vecchia C, Autier P and Boyle P, Carsinogenesis., 2007, 28(5), 913-915.

3. Gohar A V and Muhammadi A, J Biol Sci., 2010, 10(3), 200-208.

4. Caylak E, Aytekin M and Halifeoğlu I, Exp Toxicol Pathol., 2008, 60(4-5), 289-294.

5. Caylak E and Halifeoglu I, Cocuk Sagligi ve Hastaliklari Dergisi, 2010, 53(2), 159173. (in Turkish).

6. Pimparkar B D and Bhave A, J Assoc Physicians India., 2010, 58, 617-624, 629.

7. $\quad$ Calderon R L, Food Chemical Toxicol., 2000, 38(1 supply), 13-30.

8. Murray F J, Regul Toxicol Pharmacol., 1995, 22(3), 221-230.

9. Gasana J J, Morin J, Ndikuyeze A and Kamoso P, Environ Res Section A., 2002, 90(2), 76-88.

10. Lee R J and Cole S R, J Appl Bacteriol., 1994, 76, 270-274.

11. ITAS, Insani Tuketim Amacli Sular Hakkinda Yonetmelik, 25730 sayili Resmi Gazete, $17^{\text {th }}$ February 2005. (in Turkish).

12. Bhaskar C V, Kumar K and Nagendrappa G, E-J Chem., 2010, 7(2), 349-352.

13. Nair I V, Singh K, Arumugam M and Clarson D, E-J Chem., 2011, 8(1), 257-263.

14. Kaplan O, Yildirim N C, Yildirim N and Tayhan N, E-J Chem., 2011, 8(1), 276-280.

15. Alta L, Isik M and Kavurmaci M, J Environ Manage., 2011, (E pub ahead of print).

16. Choong T S Y, Chuah T G, Robiah Y, Gregory Koay F L and Azni I, Desalination, 2007, 217,139-166.

17. Celik I, Gallicchio L, Boyd K, Lam T K, Matanoski G, Tao X, Shiels M, Hammond E, Chen L, Robinson KA, Caulfield L E, Herman J G, Guallar E and Alberg J, Environ Res., 2008, 108(1), 48-55.

18. Liao C M, Shen H H, Chen C L, Hsu L I, Lin T L, Chen S C and Chen C J, J Hazard Mater., 2009, 165(1-3), 652-663.

19. Col M and Col C, Food Chem Toxicol., 2003, 41(10), 1417-1420.

20. Benderdour M, Bui-Van T, Dicko A and Belleville F, J Trace Elem Med Biol., 1998, 12(1), 2-7.

21. Ruiz-Payan A, Ortiz M and Duarte-Gardea M, Microchem J., 2005, 656, 1-4.

22. Den Besten P K, Adv Dent Res., 1994, 8(1),105-110.

23. Panyakapo M, Soontornchai S and Paopuree P, J Environ Sci (China), 2008, 20(3), 372-378.

24. Singer P C, J Environ Eng (New York), 1994, 120(4), 727-744. 
25. Legay C, Rodriguez M J, Sadiq R, Serodes J B, Levallois P and Proulx F, J Environ Manage., 2011, 92(3), 892-901.

26. Caballero Mesa J M, Rubio Armendariz C and Hardisson de la Torre A, Sci Total Environ., 2003, 302(1-3), 85-92.

27. Ward M H and Brender J D, Encyclopedia of Environmental Health., 2011, 167-178.

28. De Boeck M, Kirsch-Volders M and Lison D, Mutat Res., 2003, 533(1-2), 135-152.

29. Fewtrell L and Bartram J, Eds., Water quality:guidelines, standards and health. London, IWA Publishing, 2001, 289-316. 


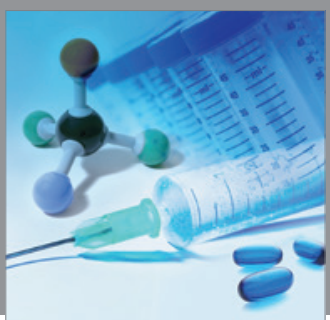

International Journal of

Medicinal Chemistry

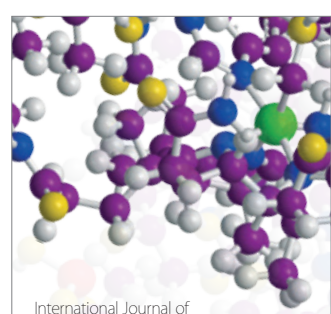

Carbohydrate Chemistry

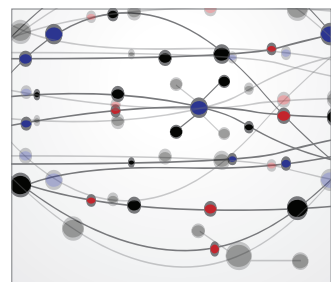

The Scientific World Journal
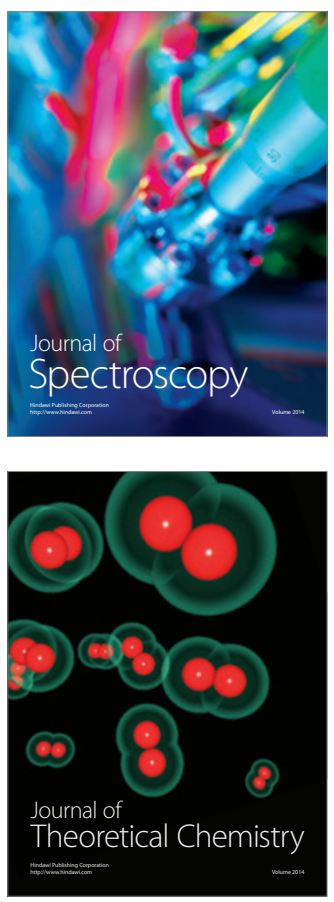
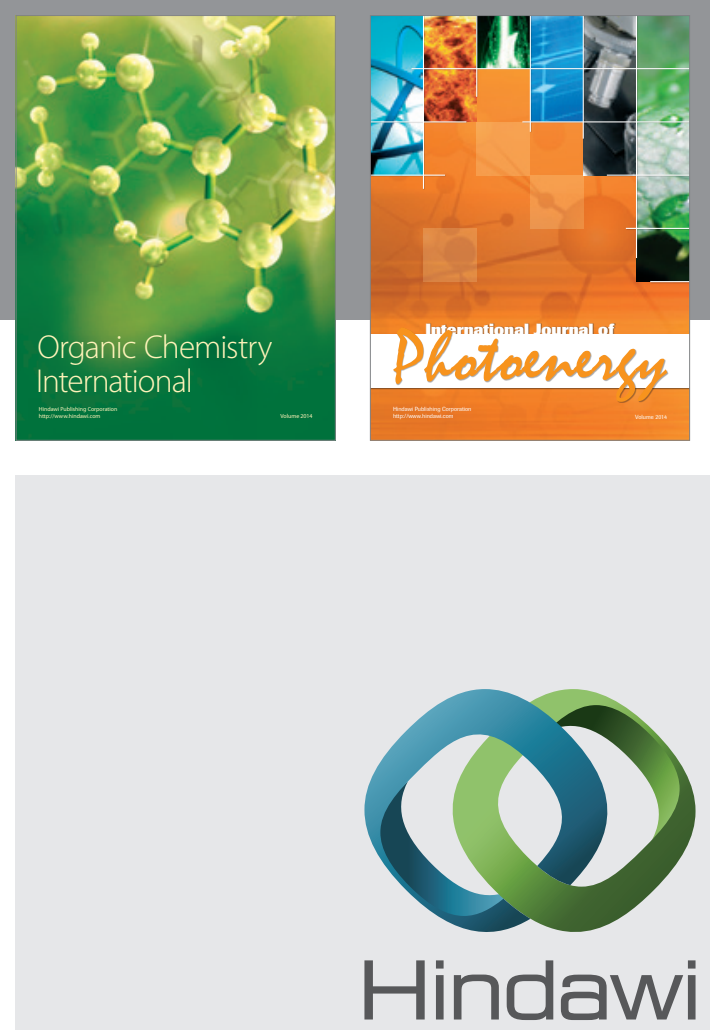

Submit your manuscripts at

http://www.hindawi.com
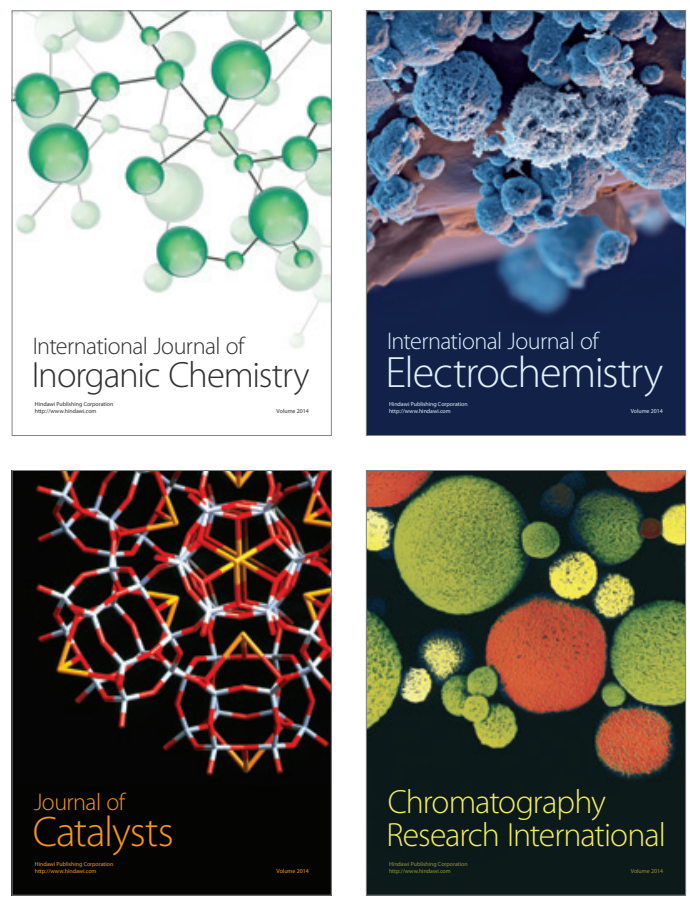
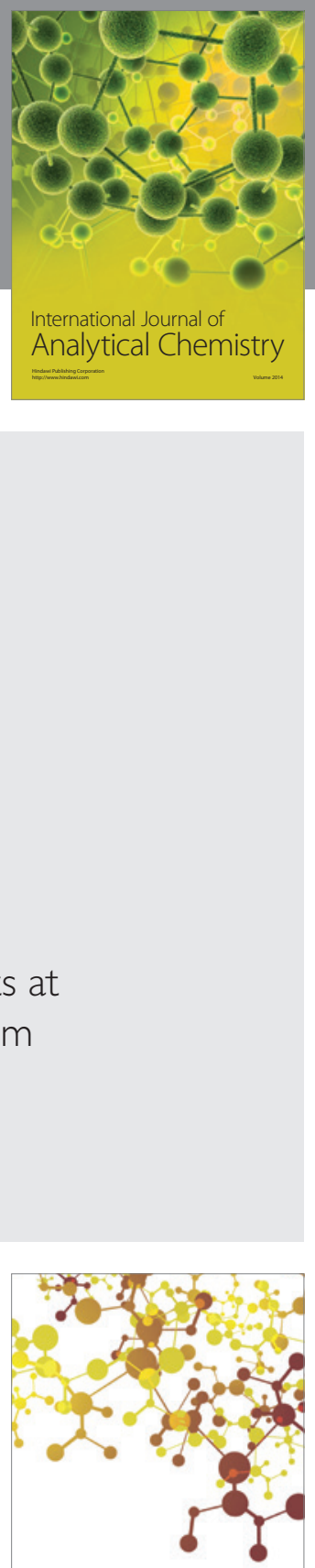

Journal of

Applied Chemistry
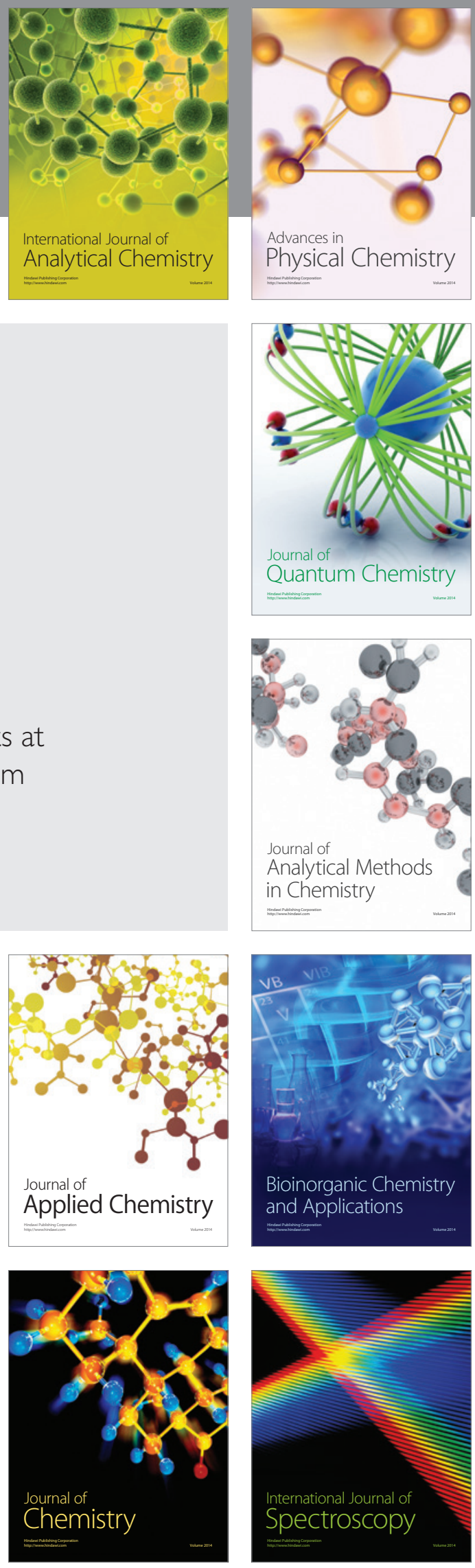